\title{
Production and use of antibodies for the detection of Taura syndrome virus in penaeid shrimp
}

\author{
B. T. Poulos ${ }^{1, *}$, R. Kibler ${ }^{2}$, D. Bradley-Dunlop ${ }^{1}$, L. L. Mohney ${ }^{1}$, D. V. Lightner ${ }^{1}$ \\ ${ }^{1}$ University of Arizona, Department of Veterinary Science and Microbiology, Tucson, Arizona 85721, USA \\ ${ }^{2}$ San Jose State University, Department of Biological Sciences, San Jose, California 95192, USA
}

\begin{abstract}
Monoclonal (MAb) and polyclonal (PAb) antibodies were produced against the penaeid shrimp virus, Taura syndrome virus (TSV), isolated from naturally infected Penaeus vannamei from farms in Ecuador, Hawaii and Texas. The PAbs produced in both chickens and mice were capable of detecting TSV in the hemolymph of shrimp during the acute phase of infection by an immunoblot assay. The MAbs were produced using BALB/cByJ mouse spleen cells fused with non-immunoglobulinsecreting SP2/0-Ag-14 mouse myeloma cells. Three MAbs of different immunoglobulin isotypes (IgGy $1 \kappa, \operatorname{Ig} G y 2 b \kappa$ and IgG $3 \kappa$ ) were compared in an immunoblot assay to determine their reactivity to hemolymph from TSV-infected shrimp during the acute and chronic phases of infection and their crossreactivity, if any, with other shrimp viruses. Western blots of purified TSV were used to compare the specificities of the 3 MAbs for the structural proteins of the virus. The MAbs were used to monitor a laboratory-induced TSV infection in juvenile $P$. vannamei, and they were capable of detecting the virus in the hemolymph of both acute and chronic phase samples. The results with chronic phase hemolymph samples were variable and indicated the need to develop an immunoassay in which the virus in a sample is captured by one antibody and then detected with a second antibody. The availability of MAbs with different specificities for TSV viral proteins and the ability to produce PAbs in chickens will make it possible to develop a sensitive capture assay for rapid detection of the virus in field situations.
\end{abstract}

KEY WORDS: TSV · Taura syndrome virus · Monoclonal antibodies Immunodetection

\section{INTRODUCTION}

Taura syndrome (TS), a serious disease of cultured penaeid shrimp, was first recognized in Ecuador in 1992 (Jimenez 1992, Wigglesworth 1994, Brock et al. 1995) during an epizootic in cultured Penaeus vannamei. The causative agent of TS was subsequently found to be a $32 \mathrm{~nm}$ icosahedral virus, possessing a single-strand of positive-sense RNA as its genome, and it was tentatively classified as a member of the family Picornaviridae (Hasson et al. 1995, Bonami et al. 1997). TS has spread rapidly throughout the Americas affecting farms in Ecuador, Peru, Columbia, Honduras, Guatemala, El Salvador, Brazil, Nicaragua, Belize, Mexico and the United States (Wigglesworth 1994, Lightner 1995, Laramore 1997, Overstreet et al. 1997). Economic losses due to TS epizootics have been devas-

•E-mail: bpoulos@u.arizona.edu tating to the shrimp farming industry, resulting in hundreds of millions of dollars in lost revenue from this virus alone (Lightner 1995). Different strategies being utilized to circumvent the disease include growing other, less susceptible species of penaeid shrimp, genetic selection of TS-resistant $P$. vannamei, complete dry-out and restocking of affected facilities and regions, and development of reliable, rapid diagnostic tests for the virus. The latter is a crucial component for any successful management program dealing with the virus.

The disease caused by Taura syndrome virus (TSV) has 3 distinct and overlapping phases: acute, transition and chronic (Hasson et al. 1995, Lightner at al. 1995, Hasson 1998). These phases were characterized in detail in Penaeus vannamei by Hasson (1998). Briefly, the acute phase of the disease typically occurs 1 to $4 \mathrm{~d}$ following initial exposure and can be evident up to $7 \mathrm{~d}$ post-exposure in some individuals. It is characterized 
histologically by the presence of multifocal cuticular epithelial lesions in the appendages, gills, hindgut, foregut and general body cuticle which present a 'peppered' or 'buckshot-riddled' appearance due to the induction of pyknotic and karyorrhectic nuclei and spherical cytoplasmic remnants. Up to $90 \%$ of an affected population of $P$. vannamei may die during this phase, with the shrimp mostly succumbing to the infection during ecdysis. If shrimp survive the acute phase of the disease, they move into a recovery or transition phase, which is seen in a population of infected shrimp during Days 5 through 8 following initial exposure to the virus. This phase is characterized by the presence of randomly distributed multifocal melanized lesions present in the cuticular epithelium and subcutis, and by the beginning of 'spheroid' formation in the lymphoid organ. If the shrimp successfully undergo another molt, the melanized lesions are cast off with the exuvium and the shrimp enter into the chronic phase of infection. The chronic phase is first seen on Day 6 post-infection and can persist for at least 8 mo (Hasson 1998). Diagnosis of TSV infection during the chronic phase is the most problematic. There are no gross signs of disease and histologically, the only remaining evidence of an infection is the presence of lymphoid organ spheroids, which are not, by themselves, diagnostic for TSV since spheroids can be induced by other pathogens (Owens et al. 1991, Bonami et al. 1992, Nadala et al. 1992, Hasson 1998). Only through the use of in situ hybridization with specific gene probes can TSV be conclusively diagnosed in chronic phase shrimp. It is currently not known if shrimp can recover completely from a TSV infection or if they remain chronically infected for life (Hasson 1998).

TSV, purified from infected shrimp tissue, was used to construct a complementary DNA (cDNA) library from which gene probes were developed (Mari et al. 1998). Several of these gene probes have been adapted for use in dot blot and in situ hybridization methods (Lightner 1996, Hasson et al. 1997). They have also been used to develop oligonucleotide primers for use in a reverse transcription-polymerase chain reaction (RT-PCR) method (Nunan et al. 1998) The use of in situ hybridization using specific cDNA gene probes has been invaluable for characterizing TSV and for detecting the virus in chronically infected shrimp. The RT-PCR method has proven to be a sensitive technique for detection of the virus in hemolymph samples during all stages of the disease although the method has not yet been adapted for use with tissues or fixed samples. These molecular methods for detection of TSV are sensitive and specific; however, because they are expensive to perform and because single-stranded RNA can be rapidly degraded by ubiq- uitous enzymes as well as by hydrolysis at acid or alka-

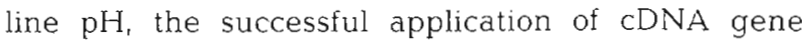
probes and RT-PCR has been limited to controlled laboratory conditions using special sample preparation methods

An alternative to the use of gene probes and PCR for virus detection in shrimp is utilization of specific antibodies directed against the relatively stable protein matrix of the viral capsid. This report describes the production of polyclonal (PAb) and monoclonal (MAb) antibodies to TSV, and the application of serological methods for rapid and sensitive detection of the virus in hemolymph from infected shrimp.

\section{MATERIALS AND METHODS}

Antigens. TSV used for immunizations was purified from naturally infected Penaeus vannamei tissue according to the procedure of Bonami et al. (1997) and was a pool of purified virus originating from 3 different geographic regions, Ecuador (Ec), Hawaii (HI) and Texas (TX). TSV used for antibody testing was purified from laboratory-induced or naturally infected $P$. vannamei tissue. The isolates from different geographic regions were not pooled for testing of the antibodies. Purity of the virus preparations was confirmed by transmission electron microscopy (TEM) using $2 \%$ phosphotungstic acid (PTA) as the negative stain and by sodium dodecyl sulfate-polyacrylamide gel electrophoresis (SDS-PAGE). Infectious hypodermal and hematopoietic necrosis virus (IHHNV) and hepatopancreatic parvo-like virus (HPV), which were used to determine antibody specificity, were purified from infected shrimp tissue according to published procedures (Bonami et al. 1990, 1995). Hemolymph, collected from the ventral sinus using $10 \%$ sodium citrate to prevent coagulation, was obtained from shrimp infected with TSV, IHHNV, white spot syndrome virus (WSSV) and yellow head virus (YHV), and from specific pathogen-free (SPF) $P$. vannamei (Wyban 1992), which were negative for all of the above viral pathogens. The disease status of the shrimp was confirmed by routine hematoxylin and eosin staining of fixed tissues (Lightner 1996).

Polyclonal antibody production. Three week old white leghorn chickens were injected subcutaneously with purified TSV emulsified in the synthetic adjuvant LES+STM ${ }^{\text {TM }}$ (RIBI Immunochem Research, Inc., Hamilton, MT). Five week old BALB/cByJ mice (Jackson Laboratories, Bar Harbor, ME) were injected intraperitoneally with purified TSV emulsified in the synthetic adjuvant MPL+TDM ${ }^{\mathrm{TM}}$ (RIBI Immunochem Research, Inc.). The sera were collected after 3 to 5 booster immunizations at 14 to $21 \mathrm{~d}$ intervals. 
Monoclonal antibody production. Spleen cells were obtained from 1 of the mice used for PAb production $2 \mathrm{~d}$ after the third TSV immunization. SP2/0-Ag-14 myeloma cells (American Type Culture Collection, Rockville, MD), pretreated with 8-azaguanine (Sigma Chemical Co., St. Louis, MO), were fused with the mouse spleen cells using polyethylene glycol 4000 (gas chromatography grade; Curtin Matheson Scientific, Houston, TX) according to previously described protocols (Kohler \& Milstein 1976, Kearney et al. 1979, Oi \& Herzenberg 1980). The resultant hybridoma cell cultures were tested for the production of immunoglobulin G (IgG) antibodies specific for TSV by dot blot immunoassay. Positive hybrids were selected and cloned 3 or more times by limiting dilution (Galfre \& Milstein 1981). Monoclonal antibodies were harvested from hybridomas grown in protein-free hybridoma medium (PFHM-II; Life Technologies, Gibco BRL, Grand Island, $\mathrm{NY}$ ) for 7 to $10 \mathrm{~d}$ at $37^{\circ} \mathrm{C}$ with $5 \% \mathrm{CO}_{2}$. The MAbs produced in PFHM-II were concentrated 8 to 10 times using Centriprep-30 ${ }^{\mathrm{TM}}$ centrifugal concentrators (Amicon, Inc., Beverly, MA). They were isotyped using the IsoStrip ${ }^{T M}$ mouse monoclonal antibody isotyping kit (Boehringer Mannheim Corp., Indianapolis, IN) according to the manufacturer's directions.

Dot blot immunoassay. Antibodies were assayed by dotting $1 \mu$ l of test antigen (purified virus, infected shrimp hemolymph or SPF shrimp hemolymph) onto the surface of MA-HA-N45 assay plates (Millipore, South San Francisco, CA). After air drying, the wells were blocked for $1 \mathrm{~h}$ at room temperature (RT) with $200 \mu \mathrm{l}$ of a buffer containing phosphate buffered saline and $0.05 \%$ Tween 20 (PBST) mixed with $10 \%$ normal goat serum (Life Technologies, Gibco BRL) and $2 \%$ Hammersten casein (Amersham Life Sciences, Arlington Heights, IL). The wells were washed 3 times with PBST and were then reacted with $100 \mu$ primary antibody (MAb or mouse PAb) for 30 min at RT. Alkaline phosphatase (AP) labeled goat anti-mouse IgG, $\gamma$ chain specific, secondary antibody (Zymed, South San Francisco, CA) diluted 1:1000 in PBST plus 10\% normal goat serum was used for detection ( $30 \mathrm{~min}, \mathrm{RT}$ ). After washing 3 times with PBST, 1 time with PBS and 1 time with distilled water, the reactions were visualized by development for $15 \mathrm{~min}$ at $\mathrm{RT}$ with nitroblue tetrazolium and bromo-chloro-indoyl phosphate (Boehringer Mannheim Corp.) in Tris- $\mathrm{NaCl}$ (100 mM each) buffer containing $50 \mathrm{mM} \mathrm{MgCl}, \mathrm{pH}$ 9.5. Reactions were stopped with distilled water. In assays employing the chicken PAb, an AP-labeled rabbit anti-chicken IgG (Sigma Chemical Co.), diluted 1:1000, was used as the secondary antibody. The reactions were graded such that a maximum +4 intensity was equivalent to the reaction generated using the mouse anti-TSV PAb at a dilution of 1:1000 against purified TSV or infected hemolymph. A negative reaction was one in which no colored spot was visible in the well. Normal mouse or chicken serum was used as a negative control for the primary antibody.

Western blot analysis. Structural proteins of TSV purified from individual geographic isolates were denatured in Laemmli buffer (Laemmli 1970) containing $10 \mathrm{M}$ urea and were separated using $12 \%$ SDSPAGE (Bonami et al. 1997). The proteins from the HI isolate of TSV were electro-transferred to nitrocellulose membranes using $0.5 \times$ Towbin transfer buffer (Towbin et al. 1979) for $3 \mathrm{~h}$ using $300 \mathrm{~mA}$ constant current. The membranes were reacted with specific MAbs obtained from hybridoma cell culture fluids or with mouse PAb diluted 1:1000 and the reactions were visualized as in the dot blot immunoassay. A marker, containing proteins of the following molecular weights, was run in the SDS-PAGE for reference: 97.4, 66.2, 39.2, 26.6, 21.5 and $14.4 \mathrm{kDa}$ (Boehringer Mannheim Corp.).

Detection of TSV in shrimp hemolymph. Experimental TSV infections were induced in SPF Penaeus vannamei obtained from the Oceanic Institute in Honolulu, HI (Wyban 1992). These shrimp were negative for all known viral pathogens of shrimp. A tissue homogenate was prepared from naturally infected TSVinfected shrimp carcasses (originating from $\mathrm{HI}$ ) by grinding $1 \mathrm{~g}$ of tissue in $2 \mathrm{ml}$ buffer containing $20 \mathrm{mM}$ Tris- $\mathrm{HCl}$ and $400 \mathrm{mM} \mathrm{NaCl}, \mathrm{pH} 7.4$, followed by centrifugation to pellet out the solid debris. The tissue homogenate was diluted 1:10 in $2 \%$ saline just prior to injection of SPF P. vannamei into the tail muscle. Hemolymph was collected from the ventral sinus of moribund shrimp in the acute phase of infection or from shrimp in the chronic phase. Experimental shrimp were maintained in the laboratory using modifications of the methods described in Williams et al. (1992). Shrimp were held in $30 \mathrm{l}$ glass aquaria with prepared sea water (Forty Fathoms Bio-Crystals Marinemix, Marine Enterprises International, Inc, Baltimore, MD) at 24 to $26 \mathrm{ppt}$ salinity, $28^{\circ} \mathrm{C}$. The aquaria were fitted with a biological filter containing crushed oyster shells and granulated carbon. Water was recirculated through the filter by an airlift. Aeration for the air lifts and the water was generated by an electric air pump and delivered to the tanks with Teflon air lines.

\section{RESULTS}

\section{Antigen purification}

TSV used for antigen was purified from naturally infected shrimp tissue originating from 3 geographic regions: Ec, HI and TX. TSV from the 3 regions was 
pooled for immunization. Purified virus preparations were examined by TEM after negative staining with $2 \%$ PTA and were determined to be free of other infectious agents (data not shown; Hasson et al. 1995 and Bonami et al. 1997 for representative TEMs of TSV). Analysis of SDS-PAGE gels of purified TSV preparations revealed only the presence of 1 minor $(58 \mathrm{kDa}$ ) and 3 major $(24,40$ and $55 \mathrm{kDa}$ ) protein bands which are characteristic for TSV (Bonami et al. 1997). Fig. 1 shows the SDS-PAGE gel for the HI isolate of TSV. There were no differences seen in the electrophoretic patterns of TSV from HI, EC or TX (data not shown).

\section{Antibody titrations}

Antibody titers were determined by dot blot immunoassay against purified TSV (HI isolate), TSVinfected hemolymph (HI isolate) and SPF hemolymph from uninfected Penaeus vannamei. The chicken and mouse PAbs displayed weak cross-reactivity to SPF hemolymph which was evident only at dilutions
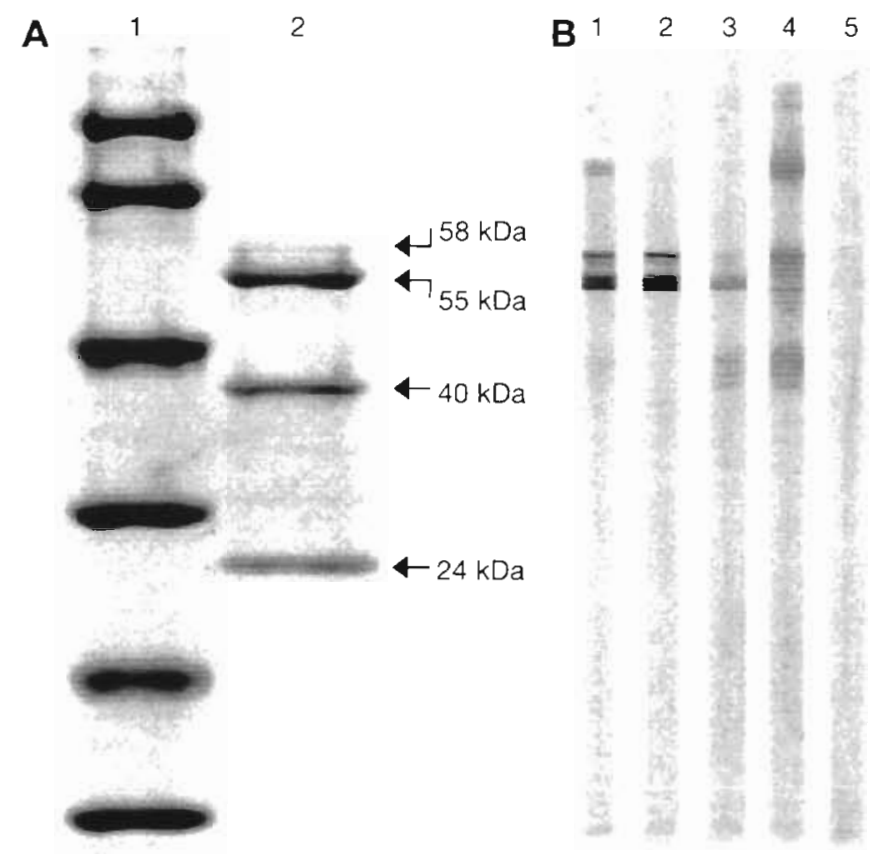

Fig. 1. (A) Sodium dodecyl sulfate-polyacrylamide gel electrophoresis (SDS-PAGE) gel and (B) Western blot of purified TSV (HI). (A) SDS-PAGE gel stained with Coomassie blue: lane 1 contains molecular weight markers with bands at 97.4 , $66.2,39.2,26.6,21.5$ and $14.4 \mathrm{kDa}$ i lane 2 contains polypeptides from purified TSV. (B) Western blot of purified TSV polypeptides: lane 1 reacted with mouse polyclonal antibody diluted 1:1000; lane 2 reacted with monoclonal antibody (MAb) $1(\gamma 1 \kappa)$; lane 3 reacted with MAb $2(\gamma 2 b x)$; lane 4 reacted with MAb $3(\gamma 3 \kappa)_{i}$ lane 5 reacted with secondary antibody only below 1:250 (Table 1). The mouse PAb had a much higher titer against purified TSV and TSVinfected hemolymph than did the chicken PAb (Table 1). Three mouse MAbs, each with a different immunoglobulin isotype, were chosen for characterization. The titers of the MAbs produced in PFHM-II medium were determined both before and after concentration against purified TSV, TSV-infected hemolymph, and SPF hemolymph. As shown in Table 1, MAb 1 consistently had the highest titer against TSV antigens and demonstrated no crossreactivity to SPF hemolymph. MAb 2 and MAb 3 had lower titers than MAb 1 to TSV antigens but were also not cross-reactive with SPF hemolymph. Concentration of the MAbs resulted in increased titers against TSV antigens, with no increase in reactivity to SPF hemolymph (Table 1).

\section{Antigen specificity of MAbs}

In order to confirm the specificity of the MAbs for TSV, they were tested by dot blot immunoassay against other purified viruses of penaeid shrimp (IHHNV and HPV) and against hemolymph from shrimp infected with other shrimp viruses (IHHNV, WSSV and YHV). As shown in Table 2, MAbs 1 and 2 were specific for TSV and TSV-infected hemolymph, whereas MAb 3 demonstrated cross-reactivity to hemolymph from IHHNV-, YHV-and WSSV-infected shrimp. The MAbs reacted to purified TSV from all 3 geographic regions, HI, Ec and TX. A secondary antibody control, in which PFHM-II medium without any $\mathrm{MAb}$ was used in place of the primary antibody, demonstrated no background reactions to the antigens tested.

\section{Western blot analysis of mouse antibodies}

Western blots were performed only with the HI isolate of TSV In Western blots, the mouse PAb (1:1000) reacted strongly to the 55 and $58 \mathrm{kDa}$ TSV polypeptides (Fig. 1B, lane 1). The Western blot showed a faintly reacting, discreet band located just below the $58 \mathrm{kDa}$ region. This faint band was not noted in Coomassie stained gels and its significance is unknown. A very weak reaction to the $40 \mathrm{kDa}$ polypeptide was also noted which was visible at a dilution of 1:500 (not shown). The PAb also displayed a weak reaction to an additional band not seen in the Coomassie stained gel which was approximately $70 \mathrm{kDa}$ in size. The MAbs demonstrated differences in their polypeptide binding patterns. MAb 1 (Fig. 1B, lane 2) 
Table 1. Titer of polyclonal (PAb) and monoclonal antibodies (MAb) to TSV ( $\mathrm{HI}$ ), before and after concentration, as assessed by dot blot immunoassay. Concentrated MAbs were processed as described in the text and were 3 to 4 times more concentrated than the original hybridoma cell culture fluids The titer is the reciprocal of the highest dilution giving $a+3$ or greater reaction

\begin{tabular}{|lrcc|}
\hline Antibody & Puritied TSV & $\begin{array}{c}\text { TSV }+ \\
\text { hemolymph }\end{array}$ & $\begin{array}{c}\text { TSV - } \\
\text { hemolymph }\end{array}$ \\
\hline Chicken PAb & 2000 & 500 & $<250$ \\
Mouse PAb & 32000 & 8000 & $<250$ \\
MAb 1 $(\gamma 1 \kappa)$ & 512 & 256 & $<2$ \\
MAb 2 $(\gamma 2$ b $)$ & 64 & 16 & $<2$ \\
MAb 3 $(\gamma 3 \kappa)$ & 128 & 128 & $<2$ \\
MAb 1 concentrated & 16384 & 8196 & $<4$ \\
MAb 2 concentrated & 1024 & 64 & $<4$ \\
MAb 3 concentrated & 1024 & 1024 & $<4$ \\
& & & \\
\hline
\end{tabular}

reacted strongly to the 55 and $58 \mathrm{kDa}$ polypeptides. It also showed a faint reaction to the band located just below the $58 \mathrm{kDa}$ polypeptide which was not evident in Coomassie stained gels. MAb 2 (Fig. 1B, lane 3) demonstrated a moderate reaction to the $55 \mathrm{kDa}$ TSV polypeptide, a weak reaction to the $40 \mathrm{kDa}$ polypeptide and a barely visible reaction to the $58 \mathrm{kDa}$ polypeptide. MAb 3 (Fig. 1B, lane 4) reacted weakly to the $55 \mathrm{kDa}$ TSV polypeptide and moderately to the 58 and $40 \mathrm{kDa}$ TSV polypeptides. It also reacted to the $70 \mathrm{kDa}$ band and to the band located just below the $58 \mathrm{kDa}$ polypeptide which were not seen in Coomassie stained gels (Fig. 1A, lane 2). With MAb 3, a reaction was also noted at the top of the membrane which corresponded to the top of the resolving gel and was presumably protein that was too large to migrate in the gel during electrophoresis. Neither the MAbs nor the PAb reacted with the $24 \mathrm{kDa}$ polypeptide. The secondary

Table 2. Specificity of anti-TSV MAbs assessed by dot blot immunoassay. Reactions were scored on a scale of increasing intensity $(+1$ to +4$)$. TSV negative $(-)$ hemolymph was obtained from specific pathogen-free shrimp

\begin{tabular}{|lccc|}
\hline Antigen & $\begin{array}{c}\text { MAb 1 } \\
(\gamma \text { 1 })\end{array}$ & $\begin{array}{c}\text { MAb 2 } \\
(\gamma \text { 2b })\end{array}$ & $\begin{array}{c}\text { MAb 3 } \\
(\gamma 3 \kappa)\end{array}$ \\
\hline Purified TSV (EC) & +3 & +3 & +3 \\
Purified TSV (HI) & +4 & +3 & +3 \\
Purified TSV (TX) & +3 & +3 & +3 \\
TSV + hemolymph (HI) & +4 & +3 & +4 \\
TSV - hemolymph & - & - & - \\
Purified IHHNV & - & - & - \\
IHHNV + hemolymph & - & - & +2 \\
Purified HPV & - & - & - \\
YHV + hemolymph & - & +1 & +2 \\
WSSV + hemolymph & - & - & +4 \\
\hline
\end{tabular}

antibody did not display reactivity to any of the polypeptides.

\section{Detection of TSV in shrimp hemolymph}

Hemolymph was obtained from shrimp during the acute ( 1 to $5 \mathrm{~d}$ post-infection) and chronic ( 6 to $10 \mathrm{~d}$ post-infection) phases of a TSV infection. For the purposes of this study, no distinction was made for the transition phase and shrimp in this phase were grouped with the chronic phase shrimp. The samples were tested by immunoblot assay using MAb 1 as the primary antibody. MAb 1 was capable of detecting TSV in all of the samples during the acute phase with the majority of reactions $(21 / 24)$ ranging from +2 to +4 (Table 3). During the chronic phase, MAb 1 was also able to detect TSV in all of the samples, but the reactions were less intense and more variable with the majority of the reactions $(14 / 16)$ ranging from +1 to +3 intensity (Table 3).

\section{DISCUSSION}

The primary purpose of this study was the development of highly specific monoclonal antibodies to TSV which can be produced economically and used to develop rapid immunoassays for detection of the virus in field situations. Three different mouse hybridoma cell lines were obtained which produce monoclonal antibodies against TSV and which have different immunoglobulin isotypes. The IgG $\gamma 1 \mathrm{~K}$ isotype MAb (MAb 1) consistently demonstrated the highest titer and the most specific reactions when compared with the IgG $\gamma 2 \mathrm{~b}$. isotype MAb (MAb 2) and the IgG $\gamma 3 \kappa$ isotype MAb (MAb 3). All 3 of the MAbs reacted with more than a single band in Western blots. MAb 1 reacted strongly with the 58 and $55 \mathrm{kDa}$ TSV structural

Table 3. Summary of dot blot immunoassay results of hemolymph samples from Penaeus vannamei infected with TSV (HI) and reacted with monoclonal antibody MAb $1(\gamma 1 \kappa)$. Reactions were scored on a scale of increasing intensity $(+1$ to +4$)$. Acute phase samples were collected 1 to $5 \mathrm{~d}$ postinfection and chronic phase samples were collected 6 to $10 \mathrm{~d}$ post-infection with TSV

\begin{tabular}{|lcc|}
\hline $\begin{array}{l}\text { Immunoblot } \\
\text { reaction }\end{array}$ & $\begin{array}{c}\text { Acute phase } \\
\text { (No. reacting/total) }\end{array}$ & $\begin{array}{c}\text { Chronic phase } \\
\text { (No. reacting/total) }\end{array}$ \\
\hline Negative & $0 / 24$ & $0 / 16$ \\
+1 & $3 / 24$ & $5 / 16$ \\
+2 & $8 / 24$ & $4 / 16$ \\
+3 & $4 / 24$ & $5 / 16$ \\
+4 & $9 / 24$ & $2 / 16$ \\
\hline
\end{tabular}


proteins by Western blot analysis, whereas MAb 2 reacted with only moderate intensity to the 55 and $40 \mathrm{kDa}$ structural proteins. MAb 3 reacted with the 58. 55 and $40 \mathrm{kDa}$ TSV proteins as well as to other bands which were not evident in the stained gel. The PAb and 2 of the MAbs (1 and 3) also reacted very faintly to bands not seen in Coomassie stained gels. The significance of these bands is not known. They may be TSV proteins that occur in very low concentrations and are therefore not evident by Coomassie blue staining, or they may be shrimp proteins which co-purified with the virus. Regardless, they were present in the antigen preparation used for immunization since the PAb demonstrated reactivity to them by Western blot analysis. The lack of reactivity to the $24 \mathrm{kDa}$ polypeptide by any of the MAbs or the mouse PAb indicates that this protein is not highly immunogenic in mice. The chicken PAb also did not react to the $24 \mathrm{kDa}$ polypeptide (data not shown).

The multiple reactivities seen with the MAbs in the Western blots may have several explanations. In the case of MAb 1, the antibody was shown to be highly specific for TSV by immunoblot reactions and it was produced from a stable hybridoma that had been subcloned 7 times before the antibody was harvested for Western blot analysis. It is likely that the reaction to the 55 and $58 \mathrm{kDa}$ bands is due to the presence of common epitopes in these 2 capsid proteins. There are examples of proteolytic breakdown of polypeptides in other picorna-like viruses in which the resulting capsid proteins have identical stretches of amino acid sequences, but differ in their length. This is best exemplified by the capsid proteins of the aphid picorna-like virus, Acyrthosiphon pisum virus (APV; Van Der Wilk et al. 1997). In APV, the 4 capsid proteins all share an identical 16 amino acid sequence. Based on analysis of the DNA and amino acid sequence data, the authors conclude that the $23 / 24 \mathrm{kDa}$ protein is a proteolytic breakdown product of the $34 \mathrm{kDa}$ protein, whereas the $66 \mathrm{kDa}$ protein is the result of a translational frameshift which occurs downstream of the region of amino acid identity of the capsid proteins. In another example, an insect virus in the Nodaviridae family exhibits spontaneous cleavage of the major capsid protein in the mature virion (Schneemann et al. 1992). In SDS-PAGE gels of mature virions, the precursor protein is a minor band only slightly larger than the major capsid protein. The small protein cleaved from the precursor is only $5 \mathrm{kDa}$ in size, stains poorly with Coomassie brilliant blue and is often not visible in the gels. The presence of a common epitope may also explain the reactivity of $\mathrm{MAb} 2$, which reacted to the $55 \mathrm{kDa}$ and $40 \mathrm{kDa}$ capsid proteins in Western blots and also demonstrated specificity for TSV in immunoblot tests. Conclusive evidence for the presence of identical amino acids shared by the 58,55 and $40 \mathrm{kDa}$ capsid proteins must await final DNA and amino acid sequence analyses of TSV, which is in progress by Dr Jocelyne Mari in our laboratory at the University of Arizona (pers. comm.).

In the case of MAb 3, numerous bands reacted in the Western blot and all of them were of low or moderate intensity. Considering the data from the immunoblots where MAb 3 cross-reacted with hemolymph from shrimp infected with other viruses, the results indicate that MAb 3 is probably a low avidity antibody which results in non-specific binding. If this is correct, then MAb 3 will not be a useful antibody for the development of specific test formats for TSV.

The TSV used in Western blots was purified from tissue originating in $\mathrm{HI}$. Future work will determine if the same reaction pattern is seen with TSV purified from tissue originating in Ec and TX since a pool of these 3 geographic isolates was used to immunize the mice for the production of the hybridomas. In the characterization of the viral agent, Bonami et al. (1997) found the Ec and HI TSV isolates to be identical in their biophysical, biochemical and biological characteristics. MAb 1 can be used to assist in determining if TSV isolates from these different geographic regions are also serologically identical.

TSV has been suggested for inclusion in the family Picornaviridae (Hasson et al. 1995, Bonami et al. 1997). It is like other picornaviruses with respect to the size, shape and buoyant density of the viral particle and with respect to the type and size of the genome (Murphy et al. 1995). However, TSV is unique from other picornaviruses in the number and sizes of the structural proteins as determined by SDS-PAGE analysis: only 3 major capsid proteins have been identified in TSV which are seen in approximately equal molar ratios (Bonami et al. 1997). The Western blot reactivity of MAb 1, and possibly MAb 2, indicate that there may be some regions of amino acid similarity in the capsid proteins which would further differentiate TSV from mammalian picornaviruses, but which would align it more closely with other picorna-like viruses of insects.

Since MAb 1 demonstrated the strongest and most specific reactivity to TSV, it was employed to assess the efficacy of using a direct immunoblot assay for detection of TSV in acute and chronic phase hemolymph samples. The results demonstrate that the direct immunoblot assay is sufficient for detection of TSV in acute phase hemolymph samples, but that it is not sensitive enough for consistent detection of the virus during the early chronic phase of infection. Using TSV purified from infected shrimp tissue, it was also possible to produce polyclonal antibodies to the virus. Polyclonal antibodies were produced in both chickens and mice. The availability of chicken anti-TSV antibodies offers potential for development of antigen 
'capture' assays in which a second antibody may be employed to detect the captured virus. This is currently being investigated as a way to provide for more sensitive detection of TSV from chronic phase hemolymph.

The data presented here demonstrate the specificity of MAbs and PAbs produced to the penaeid shrimp virus TSV. Furthermore, the results indicate that MAb 1 will be useful in the development of other serological test formats such as immunofluorescent antibody tests that will permit the rapid detection of TSV in shrimp tissue or hemolymph. Recently, Luis Matheu (Universidad del Valle de Guatemala, pers. comm.) tested MAb 1 on TSV-infected fixed tissue sections using a goat anti-mouse AP conjugate for final detection and demonstrated reaction patterns that matched serial sections which had been tested with a TSV specific gene probe. The data reveal that antibodies produced to TSV can be employed for sensitive in situ histological analysis and may provide tools for further study of TS viral pathogenesis in penaeid shrimp. It may also be possible to utilize these antibodies for purification of virions from infected samples or for purification of structural viral proteins by attachment of the antibodies to an affinity column matrix.

Acknowledgements. Support for this research was provided by the Gulf Coast Research Laboratory Consortium Marine Shrimp Farming Program, CSREES, USDA under Grant No. 95-38808-1424, the National Marine Fisheries Service (Saltonstall-Kennedy Act), USDC under Grant No. NA56FD0621, the SBIR, in conjunction with DiagXotics (Wilton, CT), USDA under Award No. 96-33610-2612 and by Cultivos Marinos, S.A. de C.V. based in Honduras, Central America. Ms Beth Ann Ayala is acknowledged for her assistance in the preparation of the chicken polyclonal antibodies.

\section{LITERATURE CITED}

Bonami JR, Trumper B, Mari J, Brehelin M, Lightner DV (1990) Purification and characterization of the infectious hypodermal and hematopoietic necrosis virus of penaeid shrimps. J Gen Virol 71:2657-2664

Bonami JR, Lightner DV, Redman RM, Poulos BT (1992) Partial characterization of a togavirus (LOVV) associated with histopathological changes of the lymphoid organ of penaeid shrimps. Dis Aquat Org 14:145-152

Bonami JR, Mari J, Poulos BT, Lightner DV (1995) Characterization of hepatopancreatic parvo-like virus, a second unusual parvovirus pathogenic for penaeid shrimps. J Gen Virol 76:813-817

Bonami JR, Hasson KW, Mari J, Poulos BT, Lightner DV (1997) Taura syndrome of marine penaeid shrimp: characterization of the viral agent. J Gen Virol 78:313-319

Brock JA, Gose R, Lightner DV, Hasson KW (1995) An overview on Taura syndrome, an important disease of farmed Penaeus vannamei. In: Browdy CL, Hopkins JS (eds) Proceedings of the special session Swimming Through Troubled Water. World Aquaculture Society, Baton Rouge, LA, p 84-94
Galfre G, Milstein C (1981) Preparation of monoclonal antibodies: strategies and procedures. Methods Enzymol $73 \mathrm{~B}: 3-46$

Hasson KW (1998) Taura syndrome of marine penaeid shrimp: discovery of the viral agent and disease characterization studies. Final dissertation for the completion of the PhD in the Pathobiology Program, Department of Veterinary Science and Microbiology, University of Arizona, Tucson, AZ, p 1-360

Hasson KW, Lightner DV, Poulos BT, Redman RM, White BL, Brock JA, Bonami JR (1995) Taura syndrome in Penaeus vannamei: demonstration of a viral etiology. Dis Aquat Org 23:115-126

Hasson KW, Hasson J, Aubert H, Redman RM, Lightner DV (1997) A new RNA-friendly fixative for the preservation of penaeid shrimp samples for virological detection using cDNA genomic probes. J Virol Methods 66:227-236

Jimenez R (1992) Sindrome de Taura (resumen). In: Acuacultura del Ecuador. Camara Nacional de Acuacultura. Guayaquil, p 1-16

Kearney JF, Radbruch A, Liesegang B, Rajewsky K (1979) A new mouse myeloma cell line that has lost immunoglobulin expression but permits the construction of antibodysecreting hybrid cell lines. J Immunol 123:1548-1550

Kohler G, Milstein C (1976) Fusion between immunoglobulinsecreting and nonsecreting myeloma cell lines. Eur $J$ Immunol 6:511-519

Laemmli UK (1970) Cleavage of structural proteins during the assembly of the head of bacteriophage T4. Nature 227 : $680-685$

Laramore CR (1997) Shrimp culture in Honduras following the Taura syndrome virus. Proceedings of the IV Symposium on Aquaculture in Central America, Tegucigalpa, Honduras

Lightner DV (1995) Taura syndrome: an economically important viral disease impacting the shrimp farming industries of the Americas including the United States. Proceedings of the 99th annual meeting of the US Animal Health Association, Reno, NV

Lightner DV (1996) A handbook of shrimp pathology and diagnostic procedures for diseases of cultured penaeid shrimp. World Aquaculture Society, Baton Rouge, LA

Lightner DV, Redman RM, Hasson KW, Pantoja CR (1995) Taura syndrome in Penaeus vannamei (Crustacea: Decapoda): gross signs, histopathology and ultrastructure. Dis Aquat Org 21:53-59

Mari J, Bonami JR, Lightner DV (1998) Taura syndrome of penaeid shrimp: cloning of the viral genome fragments and development of specific gene probes. Dis Aquat Org 33:11-17

Murphy FA, Fauquet CM, Bishop DHL, Ghabrial SA, Jarvis AW, Mertelli GP, Mayo MA, Summers MD (1995) Virus taxonomy: classification and nomenclature of viruses Arch Virol 10:329-336

Nadala ECB, Lu Y, Loh PC, Brock JA (1992) Infection of Penaeus stylirostris (Boone) with a rhabdovirus isolated from Penaeus sp. Gyobyo Kenekyu 27:143-147

Nunan LM، Poulos BT, Lightner DV (1998) Reverse transcription polymerase chain reaction (RT-PCR) used for the detection of Taura syndrome virus (TSV) in experimentally infected shrimp. Dis Aquat Org 34:87-91

Oi VT, Herzenberg LA (1980) Immunoglobulin-producing hybrid cell lines. In: Mishell BB, Shiigi SM (eds) Selected methods in cellular immunology. WH Freeman, San Francisco, CA, p 351-372

Overstreet RM, Lightner DV, Hasson KW, Mcllwain S, Lotz JM (1997) Susceptibility to Taura syndrome virus of some pe- 
naeid shrimp species native to the Gulf of Mexico and the southeastern United States. J Invertebr Pathol 69:165-176

Owens L, DeBeer S, Smith J (1991) Lymphoidal parvoviruslike particles in Australian penaeid prawns. Dis Aquat Org 11:129-134

Schneemann A, Zhong W, Gallagher TM, Rueckert RR (1992) Maturation cleavage required for infectivity of a nodavirus. J Virol 66:6728-6734

Towbin HT, Staehelin T, Gordon J (1979) Electrophoretic transfer of proteins from polyacrylamide gels to nitrocellulose sheets: procedure and some applications. Proc Natl Acad Sci USA 76:4350-4354

Van Der Wilk F, Dullemans AM, Verbeek M, Van Den Heuvel

Editorial responsibility: Timothy Flegel,

Bangkok, Thailand
JFJM (1997) Nucleotide sequence and genomic organization of Acyrthosiphon pisum virus. Virology 238:353-362

Wigglesworth J (1994) Taura syndrome hits Ecuador farms. Fish Farmer 17(3):30-31

Williams RR, Dehdashti B, Lightner DV (1992) Performance of an aquatic multispecies system in evaluating the effects of a model microbial pest control agent on non-target organisms. J Toxicol Environ Health 37:247-264

Wyban JA (1992) Selective breeding of specific pathogen-free (SPF) shrimp for high health and increased growth. In Fulks W, Main KL (eds) Diseases of cultured penaeid shrimp in Asia and the United States. The Oceanic Institute, Honolulu, HI, p 257-268

Submitted: June 26, 1998; Accepted: May 2, 1999

Proots received from author(s): July 27, 1999 